\title{
COMPARATIVE ANALYSIS OF DIFFERENT ACIDS UTILIZATION FOR CELLULOSIC HYDROLYSIS BY USING BRAZILIAN WOOD WASTES FOR FIBERS AND BIOETHANOL PRODUCTION YIELDS
}

\section{ANÁLISE COMPARATIVA DA UTILIZAÇÃO DE DIFERENTES ÁCIDOS PARA HIDRÓLISE CELULÓSICA UTILIZANDO RESÍDUOS DE MADEIRAS BRASILEIRAS PARA A PRODUÇÃO DE FIBRAS E BIOETANOL}

\author{
Diogo José Horst ${ }^{1}$; Rodolfo Reinaldo Petter ${ }^{2}$; Jhon Jairo Ramirez Behainne ${ }^{3}$ \\ ${ }^{1}$ Universidade Tecnológica Federal do Paraná - UTFPR - Ponta Grossa - Brasil \\ diogohorst@yahoo.com.br \\ ${ }^{2}$ Universidade Tecnológica Federal do Paraná - UTFPR - Ponta Grossa - Brasil \\ rodolfo@jjicmoveis.com.br \\ ${ }^{3}$ Universidade Tecnológica Federal do Paraná - UTFPR - Ponta Grossa - Brasil \\ jhon@,utfpr.edu.br
}

\begin{abstract}
The main objective of this paper is to determine the hydrolysis efficiency by using four different diluted treatment acids: sulfuric $\left(\mathrm{H}_{2} \mathrm{SO}_{4}\right)$, nitric $\left(\mathrm{HNO}_{3}\right)$, phosphoric $\left(\mathrm{H}_{3} \mathrm{PO}_{4}\right)$, and acetic $\left(\mathrm{CH}_{3} \mathrm{COOH}\right)$, in an attempt to improve the fibers and bioethanol production levels. In this study twelve Brazilian woods were investigated, including native and exotic species, hardwoods and softwoods. Processes to use wood waste recovery established to produce ethanol and cellulosic fibers simultaneously were carried out. For fermentation essay, a wild line of Saccharomyces cerevisiae yeast was investigated. The incomes related to hydrolysis efficiency, ethanol yields, fibrous fractions efficiency, and plus glucose and delignification levels using acid and alkaline treatments were tested. From the results it is possible to join the production of ethanol and cellulosic fibers simultaneously using wood chips, and due to the complexity of the analyzed material it's still possible to isolate byproducts. Also from results, the yeast demonstrated to be efficient with an estimate maximum production of 12.94 liters per $100 \mathrm{~kg}$ of biomass using Balfourodendron riedelianum specimen and sulfuric acid hydrolysis. All acids and samples demonstrated high and similar efficiency in hydrolysis, indicating that these are feasible for the processes.
\end{abstract}

Key-Words: hydrolysis; diluted acids; wood waste; cellulosic fibers; bioethanol.

\section{Introduction}

There is a considerable potential to modernize the use of biomass to produce fuels and convenient energy vectors such as electricity, while the traditional uses of biomass is still preserved. When produced in sufficient and sustainable ways, energy from biomass brings many environmental and social benefits if compared to other fossil fuels. Some geopolitical factors related 
to the security of oil supply, high prices and serious environmental concerns, like global warming, are essential to the sustainability through alternative fuels such as bioethanol (COPPOLA et al., 2009). Using ethanol instead of petroleum derivatives is advantageous in many aspects (KRISHNA et al., 2001; ZHU et al., 2010a; 2010b).

The development of new technologies for treatment of the lignocellulosic materials for ethanol production is well regarded by the world, both economically and environmentally, as compared to fossil fuel's production. Today, ethanol is one of the most important alternative fuels which can be obtained through the fermentation of sugars using a biological catalyst, such as yeast. Processes for producing ethanol using yeasts have been extensively investigated. In an attempt to minimize the production costs, the use of cellulosic materials, which includes agro-industrial residues and wood wastes, appears as important source of carbohydrates for biomass fermentations (SUN, 2002; CHENG, 2004).

Wood is a complex substance of polymeric character. Generally among $40 \%$ to $50 \%$ weight of dry wood consists of cellulose, which is a fiber of great commercial value. The cell walls consist of polysaccharides, lignin and holocelluloses. The holocellulose is a mixture of short-chain polymers such as arabinose $\left(\mathrm{C}_{5} \mathrm{H}_{10} \mathrm{O}_{5}\right)$, galactose $\left(\mathrm{C}_{6} \mathrm{H}_{12} \mathrm{O}_{6}\right)$, glucose $\left(\mathrm{C}_{6} \mathrm{H}_{12} \mathrm{O}_{6}\right)$, mannose $\left(\mathrm{C}_{6} \mathrm{H}_{12} \mathrm{O}_{6}\right)$ and xylose $\left(\mathrm{C}_{5} \mathrm{H}_{10} \mathrm{O}_{5}\right)$. Lignin is a complex polymer of substituted phenols that act as ligands of cellulosic fibers (FENGEL; WEGENER, 1989). Cellulose can be hydrolyzed by the action of mineral acids, unfolding into glucose.

Glucose can be fermented by yeasts to produce alcohol. In nature, these processes carried out by fungi and bacteria's, or utilizes enzymes to break down the cellulose molecules, which are called cellulases, and also by yeasts which ferment wood sugars into alcohol. The technological process of ethanol production from lignocellulosic materials can be schematically divided in three stages: (1) extraction of sugars from the raw material, (2) fermentation of sugars, and (3) distillation and rectification of fermented alcohol contained in the fermented wine. In most cases a presaccharification hydrolysis is included in the procedure to remove more easily all the hydrolysable polyoses before the mainly cellulosic hydrolysis occurs. The greatest potential for glucose utilization in biochemical processes is in fermentations to produce ethanol, but other valuable products can also be derived from wood's glucose (LEWIN; GOLDSTEIN, 1999; MARTÍN et al., 2003).

Generally, the hydrolysis yields without the pre-treatment phase are $20 \%$ of the theoretical yield, while the yield after pre-treatment is often greater than $90 \%$ of theoretical yield. It is assumed that the limited effectiveness of current enzymatic processes using soft woods is due to the relative difficulty of performing the pre-treatment of these materials. Various studies are conducted on the lignocellulosic pre-treatments (MCMILLAN, 1994; YANG et al., 2006). The hydrothermal 
treatment using water at temperatures of $170{ }^{\circ} \mathrm{C}$ to $220^{\circ} \mathrm{C}$ has been applied for pretreatment of lignocellulosic materials aimed at the solubilization of lignin's and hemicellulose's providing to these polymers subsequent enzymatic treatment leading to glucose and other saccharides production which could be used in bioprocesses of commercial interest (CHUM et al., 1990; ZHU et al., 2010).

Hydrolysis of cellulosic biomass using mineral acid is one of the methods employed to separate the lignin from monosaccharides from lignocellulosic biomass, however, this process is strongly dependent of the acid concentration and temperature. It has been reported that at low mineral acid concentrations, high temperature is required to achieve significant hydrolysis, thus requiring high energy loading. Although a high mineral acid concentration can significantly reduce temperature or the energy requirement, higher than $20 \%$ concentration of mineral acids would be needed. The process does not provide a promise for substantial industrial gains (SASAKI et al., 1998; IRANMAHBOOB et al., 2002; KAKANSON; AHLGREN, 2005) because of the difficulties in reusing and recycling the mineral acid. Therefore, establishment of an effective and environmentally benign hydrolysis process is of great significance to the conversion and the utilization of lignocellulosic biomass.

During hydrolysis, however; toxic compounds are produced, mainly derivatives of furfural, some degraded phenolic compounds and organic acids can often inhibit or undesirably effect on biocatalysts performance in bioprocesses interfering in the ferment ability when present in concentrations above $1 \%$ in weight (WOICIECHOWSKI et al., 2000). The control of the hydrolysis process aims to minimize the concentrations of toxic compounds, currently; different treatments are used for improving the capacity of hemicellulose hydrolysis fermentations (CARDONA et al., 2010; XAVIER et al., 2010; ZHU et al., 2010).

The objective of this study is to investigate the hydrolysis yields using different mineral acids: sulfuric, nitric, phosphoric, and acetic, in order to discover which hydrolysis process is more advantageous for Brazilian woods. Also, a theoretical projection to determine the ethanol yields produced in liters per $100 \mathrm{~kg}$ of biomass was carried out, as well as delignification and samples fibrous fractions efficiency. Wood chips were utilized because are considered industrial wastes with low commercial value and currently burned in boilers to generate steam and power cogeneration. This research contributes by generating new information about acid hydrolysis performance upon Brazilian wood's wastes which could be used for bioethanol production.

\section{Materials and Methods}

\subsection{Raw materials}

All lignocellulosic wastes used as samples were supplied by furniture companies from the 
states of Santa Catarina and Paraná, in the Southern region of Brazil. The material consisted of wood chips and sawdust directly obtained from industrial processes. Samples analyzed consisted of particles with 0.2 to $2.7 \mathrm{~mm}$ of diameter, (90\% or more particles passed through a $40 \mathrm{~mm}$ sieve). At this time, the wood chips were packed in containers of $5 \mathrm{~kg}$ capacity each, and then stored. Samples were originally from twelve different species of woods, among them, native and exotic species, hardwoods and softwoods, including: Hymenolobium petraeum, Tabebuia cassinoides, Myroxylon peruiferum, Nectandra lanceolata, Ocotea catharinensis, Cedrelinga catenaeformis, Cedrela fissilis Vell, Ocotea porosa, Laurus nobilis, Balfourodendron riedelianum, Pinus Elliotti, Brosimum.

\subsection{Chemicals}

All chemicals used in this work were from commercial sources. Acids were purchased from Alfa Aesar, among them: Acetic acid $\left(\mathrm{CH}_{3} \mathrm{COOH}\right)$, nitric acid $\left(\mathrm{HNO}_{3}\right)$, sulfuric acid $\left(\mathrm{H}_{2} \mathrm{SO}_{4}\right)$ and phosphoric acid $\left(\mathrm{H}_{3} \mathrm{PO}_{4}\right)$. The intention of using different acids was to identify which one can perform the most efficient hydrolysis action upon wood particles, having higher affinity to break cellulose present in the samples into glucose, for subsequent fermentation.

\subsection{Microorganism}

The yeast utilized was strains of wild Saccharomyces cerevisiae line, cultivated in the Microbiology Laboratory of the State University of Santa Catarina (UDESC). The pretreatment, hydrolysis essay, and fermentations essays also were carried out in these laboratories. This yeast was chosen because it is a widely used microorganism in bioethanol production and in other biotechnological processes. The yeast was cultivated in agar-malt slant. This agar slant consisted of malt extract (3 g/l), yeast extract (3 g/1), peptone (5 g/l), agar (10 g/l) and distilled water (up to 1 liter). Before the use as an inoculum for fermentation, the culture was aerobically propagated in 200 $\mathrm{ml}$ Erlenmeyer flasks in a shaking bath at $30^{\circ} \mathrm{C}$ for $48 \mathrm{~h}$ and then separated by centrifugation. The inoculum liquid consisted of yeast extract $(3 \% \mathrm{v} / \mathrm{v})$ and distilled water.

\subsection{Pretreatment essay}

The samples were sieved (20 mesh) in an amount of $200 \mathrm{~g}$ for each species, and then, samples were subjected to a treatment. For this treatment $250 \mathrm{ml}$ of distilled water $\left(\mathrm{H}_{2} \mathrm{O}\right)$ and $1 \%$ (volume-based) concentration using dilute acids, sulfuric, acetic, nitric and phosphoric occurs separately. After this wood chips were submitted to reaction time for $1 \mathrm{~h}$ at $120^{\circ} \mathrm{C}$. The relationship between dry weight and volume of samples solution was (1:30), established in preliminary studies Yang (2006), in which was sought to preserve the maximum integrity of shredded wood chips. After this pretreatment it was determined the hydrolysis fractions yields which corresponds to the 
glucose concentrations (cellulose transformed into hydrolyzed glucose). Glucose was identified using a blank test by replacing the acid diluted solution by distilled water.

\subsection{Efficiency of cellulosic fibers and delignification}

The fibrous fraction of lignocellulosic materials is the result of the sum of lignin and holocelulose (composed of cellulose and hemicelluloses). It's possible to obtain fibrous fractions efficiency after acid or alkaline delignification (pretreatment). In acidic ways, the samples were treated with a solution composed of glacial acetic acid 1\% and distilled water. The alkaline treatment was made using sodium hydroxide solution $(1 \% \mathrm{NaOH})$ concentration. Both treatments were kept in water bath until complete individualization of cellulosic fibers and other wood's anatomical elements.

After this, the cellulosic fibers were exhaustively washed using a fine-mesh sieve (20 meshes) and dried at $105 \pm 3{ }^{\circ} \mathrm{C}$ until acquire constant weight. The ratio between the dry weight of cellulosic fibers and initial weight of samples provided the yields of cellulosic fibers, according to methodology adopted by Krishna et al., (2001). The procedures for determining the cellulose fibers consists in taking $100.0 \mathrm{~g}$ of samples before final hydrolysis occurs and applying to it a solution of $200 \mathrm{ml}$ of $\mathrm{H}_{2} \mathrm{O}$ and diluted acetic acid $\left(1 \% \mathrm{CH}_{3} \mathrm{COOH}\right)$ and hydrogen peroxide $\left(2 \% \mathrm{H}_{2} \mathrm{O}_{2} ; 40\right.$ volumes). Then, the proceedings were kept in water bath during $1 \mathrm{~h}$ at $70{ }^{\circ} \mathrm{C} \pm 5$ and the cellulose fractions were then washed exhaustively with $\mathrm{H}_{2} \mathrm{O}$ and dried in electric oven at $105{ }^{\circ} \mathrm{C}$ till reach constant weight. The efficiency of cellulosic fibers was calculated from the following formula (1):

(1) Efficiency of cellulosic fibers (\%) = Initial weight - Final weight $\times 100$

Initial weight

\subsection{Hydrolysis and fermentation process essays}

The hydrolysis process was carried out using a stainless steel autoclave with 20 liters of total capacity at a pressure of $7 \mathrm{~kg} / \mathrm{cm}^{2}$. Operating parameters of this process were established according to Taherzadeh et al., (2001). Then, to the initial amount of $100 \mathrm{~g}$ of sawdust samples, it was added $400 \mathrm{ml}$ of distilled water for each samples and for each dilute acids concentration (1\% nitric, sulfuric, acetic, or phosphoric). After this process the samples received a suspension of calcium carbonate $\left(\mathrm{CaCO}_{3}\right)$ to stabilize the $\mathrm{pH}$ between 6.0 and 7.0 and were kept stirring during 2 hours period. This procedure consisted of final hydrolysis of the material. At this time, after $2 \mathrm{~h}$, the solution was filtered using paper filters to remove small particles and reminiscent lignin. These hydrolysate samples were subjected to fermentation essay.

The efficiency of hydrolysis process was determined as the percentage of cellulose removed from the chips and transformed into glucose. The conversion factor considerate for ethanol was 
0.56, assuming that $100.0 \mathrm{~g}$ of cellulose produces $100.0 \mathrm{~g}$ of glucose. The formula used was defined as (2):

(2) Hydrolysis Efficiency (\%) = Glucose concentration after hydrolysis

Cellulose concentration before hydrolysis

After the hydrolysis $100.0 \mathrm{~g}$ of biomass samples were fermented using twelve Erlenmeyer's with $500 \mathrm{ml}$ capacity in anaerobic conditions. Samples were inoculated using approximately 3\% (v/v) of wild Saccharomyces cerevisiae strain colony formed and $200 \mathrm{ml}$ of pure distilled water. Samples were then submitted to fermentation essay during 48 hours period at $30^{\circ} \mathrm{C}$ in controlled climate.

For distillations a mini-scale distillatory device was used, which yielded sufficient $1.000 \mathrm{ml}$ of ethanol $100 \%$ per sample. After this, using an Alcoholic Strength Table (ratio temperature and density of the mixture) passing 30 minutes for ethanol stabilization, a Gay-Lussac alcoholmeter identified alcohol $100^{\circ} \mathrm{g} / 1$ content of the prepared mixture. As this minimum quantity of produced ethanol considerate not sufficient for industrial production, the ethanol levels of samples was estimated in calculus using liters per $100 \mathrm{~kg}$ of used biomass, as will be explained in the next topic.

\subsection{Estimative of ethanol production}

For the estimate calculus of ethanol gave in liters per $100 \mathrm{~kg}$ of biomass the results were obtained by multiplying the concentration of fermentable glucose by the conversion factor of glucose to ethanol (0.56) according to Sun et al., (2002). This conversion factor was obtained by considering the normal levels of fermentation (90\%), distillation $(95 \%)$, density of ethanol at $25{ }^{\circ} \mathrm{C}$ $\left(0.785 \mathrm{~g} / \mathrm{cm}^{3}\right)$ and the molecular mass of glucose $(180.16 \mathrm{~g} / \mathrm{mol})$ and also the molecular mass of ethanol $\left(46.07 \mathrm{~g} / \mathrm{mol}^{-1}\right)$. Therefore, the results were obtained by calculus considering as a potential estimative of fermentable glucose conversion in ethanol taking in the other hand, only through using other methods of ethanol quantification such as chromatographic and by spectrometry is possible to obtain the real results of ethanol concentrations.

\section{Results and Discussion}

\subsection{Delignification and fibers efficiency}

Lignin is one of the major content in lignocellulosic materials; the amount of produced lignin by the industry could be greater according to Oliet et al., (2001). A study about yields and lignin structure changes by using acids hydrolysis process is necessary (XU et al., 2006). The meaning of delignification process carries out the efficiency of fibers production improving the ethanol yields with the extra possibility of use lignin and cellulosic fibers commercially, as 
byproducts of the process which has been expected for wood's ethanol production in sustainable molds (Zhang et al., 2010).

Delignification's using acid treatments were efficient and could well separate the cellulose fractions from lignin and still maintain the fibers fractions. The delignification rates stayed between 70.0\% using Hymenolobium petraeum and 93.3\% using Tabebuia cassinoides species (Figure 1a). In the other hand, the alkaline treatment remained between $68.0 \%$ using Hymenolobium petraeum and $92.12 \%$ also using Tabebuia cassinoides species (Figure 1b).

Figure 1a - Cellulosic fibers yields and delignification efficiency per species using acid treatment $\left(\mathrm{CH}_{3} \mathrm{COOH}\right)$.

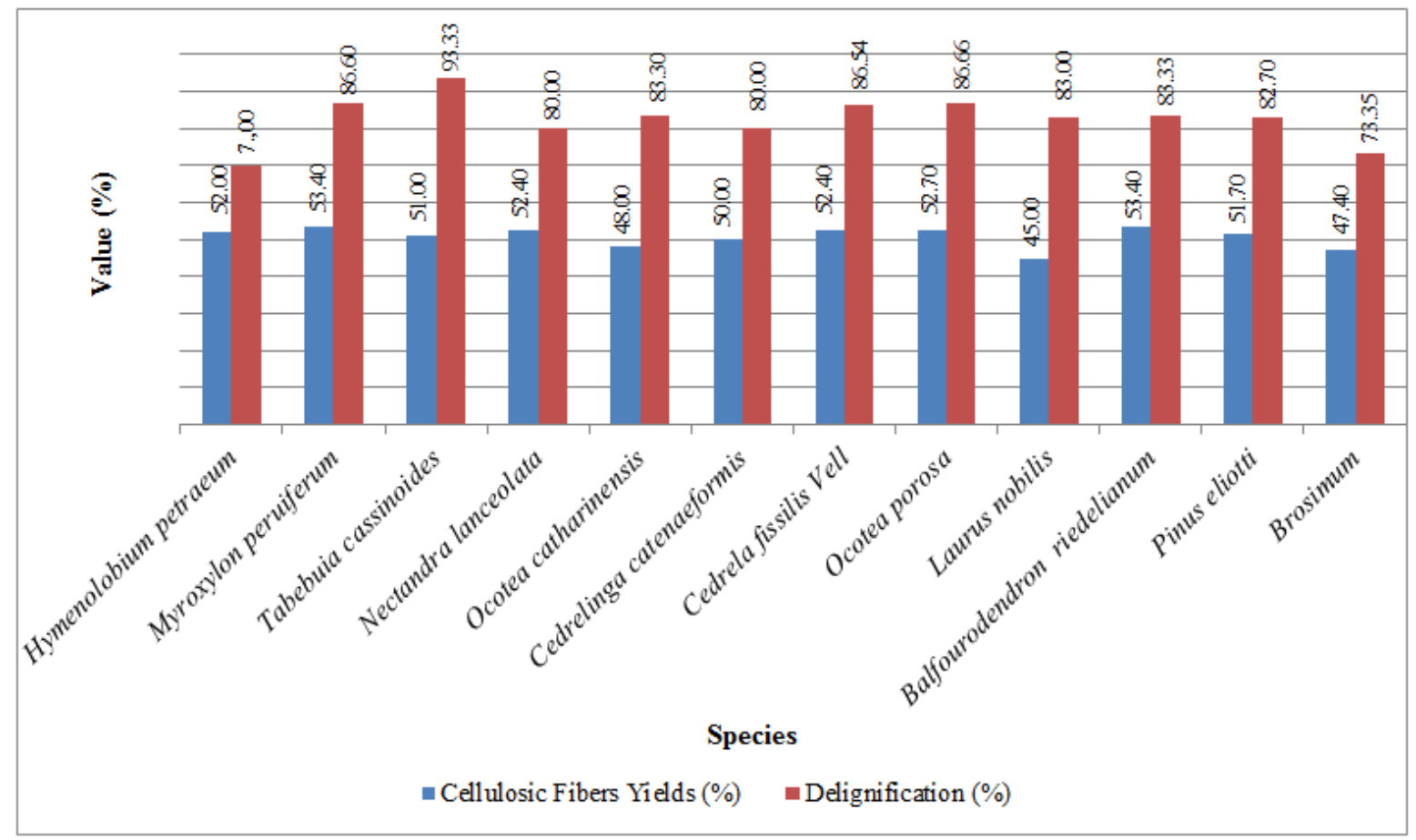

Source: Authors (2011)

Using the acid treatment (Figure 1a) the fibers yields maintained between $45.0 \%$ by using Laurus nobilis specimen and $53.40 \%$ using Myroxylon peruiferum and also by using Balfourodendron riedelianum. And delignification levels maintained between $70.0 \%$ using Hymenolobium petraeum and 93.3\% using Tabebuia cassiniodes. The differences among species chemical constitution are responsible for values disproportions. 
Figure $1 \mathrm{~b}-$ Cellulosic fibers yields and delignification efficiency per species using alkaline treatment $(\mathrm{NaOH})$

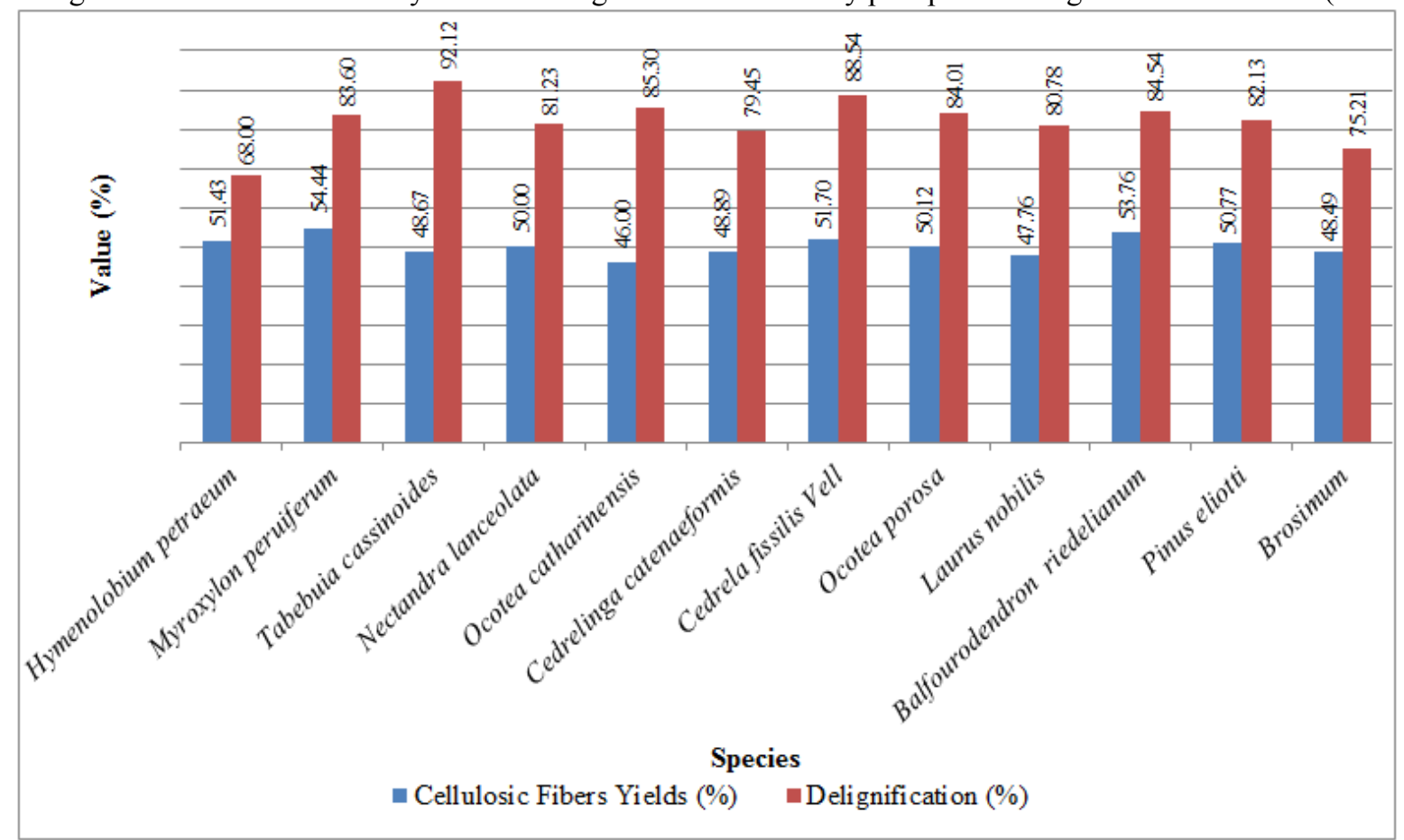

Source: Authors (2011)

Using alkaline treatment (Figure 1b) the delignification rates stays between $68.0 \%$ using Hymenolobium petraeum and $92.12 \%$ using Tabebuia cassinoides. The cellulosic fibers yields remained among $46.0 \%$ using Ocotea catharinensis and 53.76\% using Balfourodendron riedelianum.

For delignification and fibers separation both (acid and alkaline) treatments demonstrated to be very similar in efficiency. As can be observed, the cellulosic fibers and delignification's yields are related, with some exceptions. Lignin represents one of the main obstacles in using lignocellulosic materials for biotechnological applications. It is generally accepted that celluloses are irreversibly absorbed by lignin in lignocellulosic materials constitution decreasing hydrolysis efficiency. The determination of cellulosic fibers efficiency is also important for its determination in composite materials and other wood materials use which could be applied in diversified applications as byproducts. From results, as demonstrated (Figure 1a) and (Figure 1b) that it is possible to preserve the cellulosic fibers in bioethanol of wood wastes production through delignification pretreatment. Lignin previously removed can over there increase the ethanol production because lignin acts as a fermenter inhibitor for general microorganisms such as Saccharomyces cerevisiae yeast.

Also previously removed lignin can either be used in diverse industrial byproducts. So, the delignification of wood chips before fermentation becomes crucial to achieve better results in ethanol yields. The conversion of biomass into high-valued chemicals has also attracted significant attention. So, lignin can be converted to valuable products, such as carbon fiber, phenols and 
adhesives (URAKI et al., 1997; PAN; SANO, 2000).

The amounts of obtained cellulose and glucose transformation plus the hydrolysis efficiency by acids are demonstrated in (Figure 2); (Figure 3); (Figure 4); and (Figure 5). There is a direct proportion relationship between cellulose, hydrolysis, glucose, lignin, fibers and ethanol: the greater the amount of fermentable (convertible) hydrolysable cellulose, greater the volume of alcohol produced, and minor the content of lignin and fibers in hydrolysate liquor, major are the ethanol yields and major are the content of lignin and fibers for byproducts application.

Figure 2: Hydrolysis efficiency by using acetic acid $\left(\mathrm{CH}_{3} \mathrm{COOH}\right)$

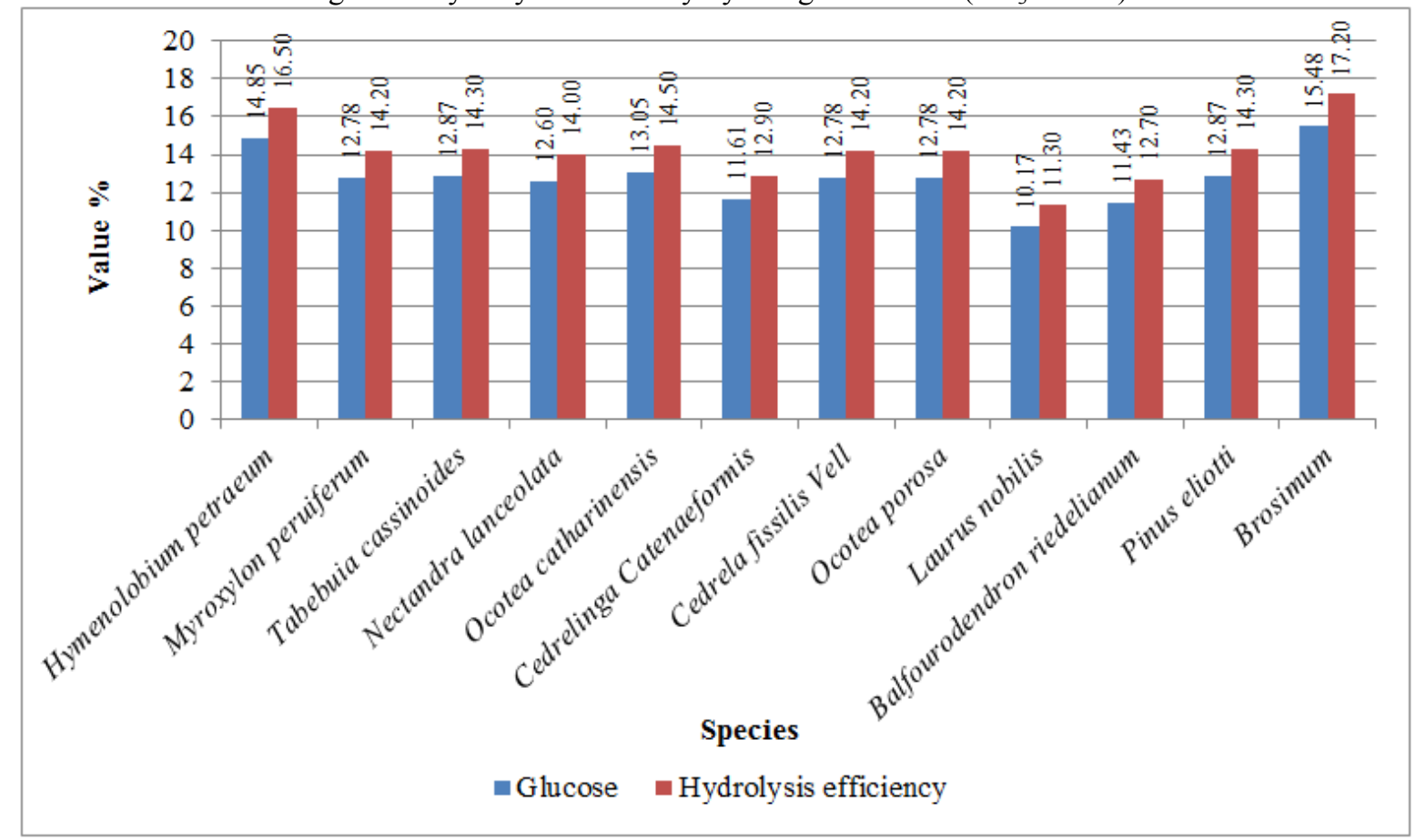

Source: Authors (2011)

According to the results, the most efficient species in hydrolysis levels by using diluted acetic acid $\left(\mathrm{CH}_{3} \mathrm{COOH}\right)$ treatment were: Brosimum 32.62\% Hymenolobium petraeum 31.35\%, and Ocotea catharinensis $27.55 \%$ species. Using this acid, the hydrolysis efficiency mantains between $21.47 \%$ and $32.62 \%$, and the glucose demonstrated rates in a range of $11.20 \%$ and $17.20 \%$ and hydrolyze cellulose efficiency rates mantained between $10.17 \%$ and $17.20 \%$ (Figure 2).

Nitric acid also provides good rates of hydrolysis transformation. Laurus nobilis $33.44 \%$ and Balfourodendron riedelianum $32.49 \%$ followed by Hymenolobium petraeum $28.50 \%$ are the most efficient hydrolyzed species using diluted nitric acid $\left(\mathrm{HNO}_{3}\right)$. The glucose rates stayed between $10.0 \%$ and $15.0 \%$ and hydrolyzed cellulose between $9.0 \%$ and $15.85 \%$ (Figure 3).

All diluted acid hydrolysis could well convert wood's hemicelluloses into monomeric sugars. The resulting hydrolyzate liquor is rich in monomeric sugars, especially in glucose, fructose and xylose. After a certain process using centrifuge - neutralization - and membrane filtration, the solid phase and most of the most quantities of fermentation inhibitors can be nearly eliminated and 
the hydrolyzate can be used as a good fermentable media to yield bio-ethanol and other valuable products (LIU et al., 2008a; 2008b).

Figure 3: Hydrolysis efficiency by using nitric acid $\left(\mathrm{HNO}_{3}\right)$

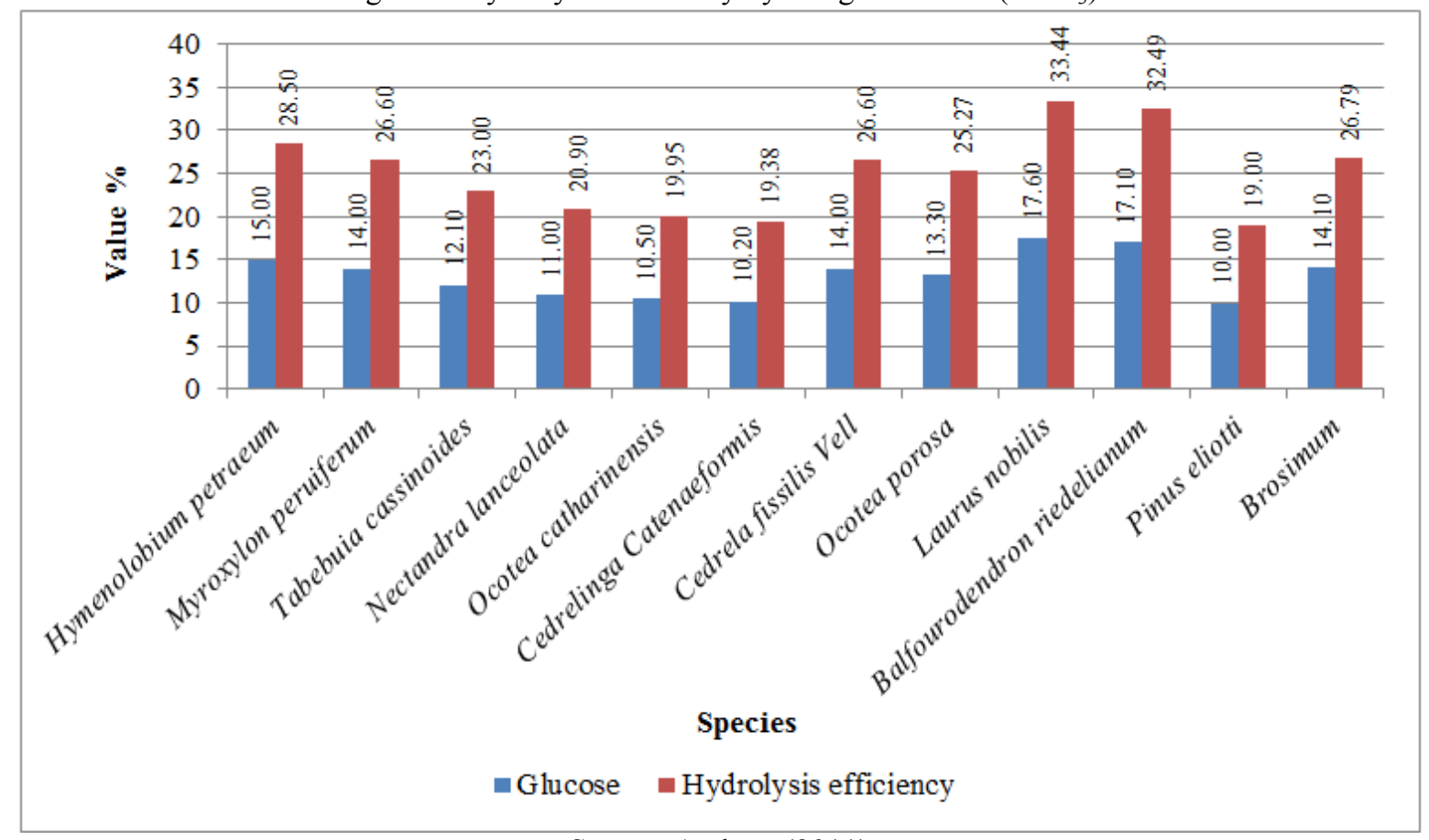

Source: Authors (2011)

Non-cellulose fractions such as lignin and hemicelluloses (accounting for $50-55 \%$ of dry weight of wood and straw) are actually in most of times used only burned to produce process energy (VILA et al., 2003). This means that $70-90 \%$ of lignin can be removed from cellulose in the microstrutural constitution of wood for best ethanol efficiency of conversion and also for produce process energy. In this work, removed lignin rate stayed between $70.0 \%$ and $93.33 \%$ which is in according to the literature for dilutted acid hydrolysis of woods. Also, the cellulosic fibers efficiency stayed between $70.0 \%$ and $97.40 \%$ demonstrating high fiber levels stimulating even more the pretreatment application keeping fibers intact with the possibility of utilization and also improving ethanol yields, since once the fibers are removed then yeast can achieve free glucose easily. 
Figure 4: Hydrolysis efficiency by using sulfuric acid $\left(\mathrm{H}_{2} \mathrm{SO}_{4}\right)$

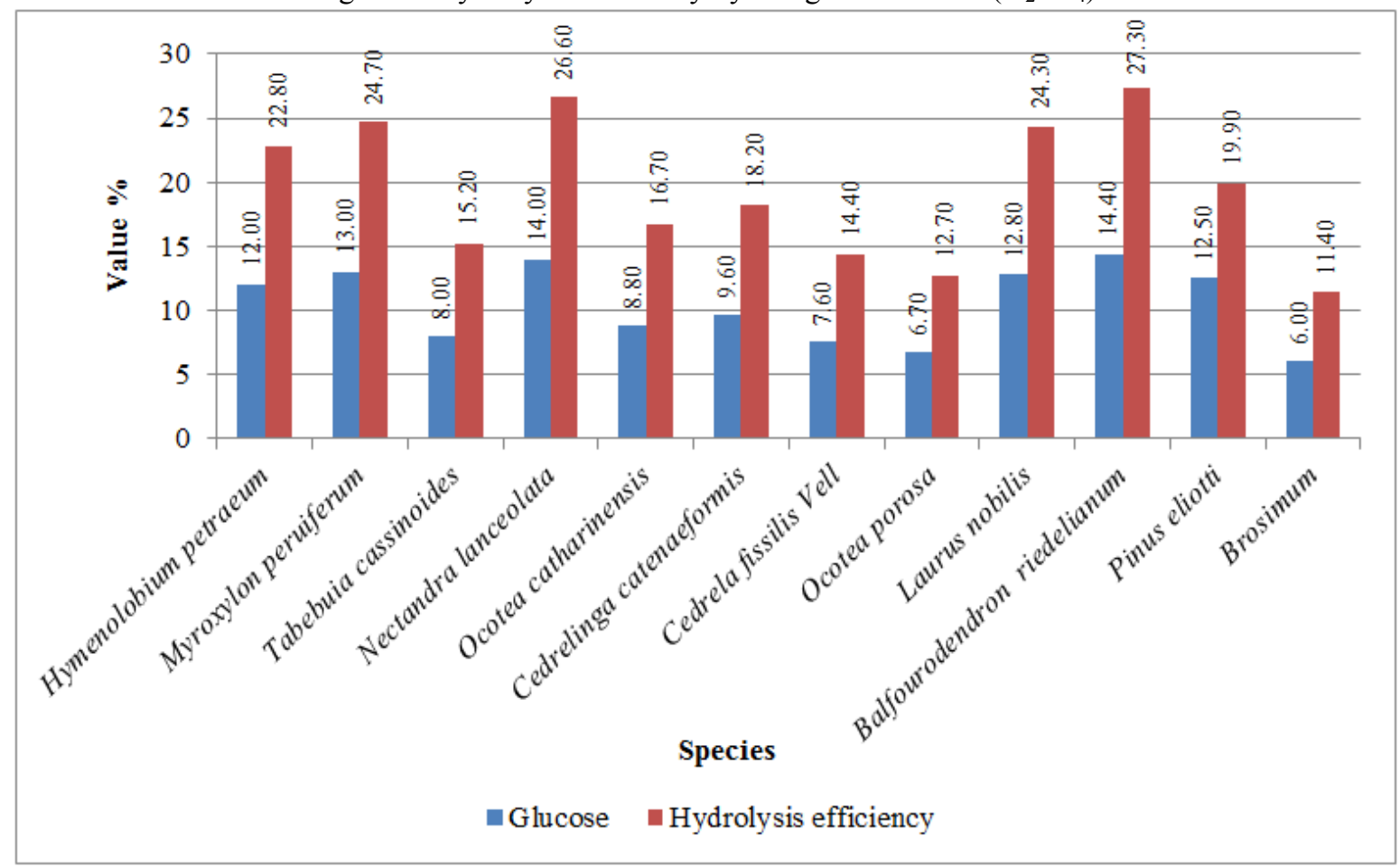

Source: Authors (2011)

According to the literature, the most used acid for hydrolysis is sulfuric diluted acid at $1 \%$ concentration Ruofei (2010). But the price of acid elevates the process costs and also sulfuric acid demands a expansive anti-corrosion equipment (IRANMAHBOOB et al, 2002). The use of diferent acids can provide practically the same or better hydrolysis results in substitute to sulfuric acid as verified in this work. The glucose concentrations and hydrolysis yields founded in this work are within the literature as according to Iranmahboob et al., (2002) using diluted sulfuric acid hydrolysis treatment and a mix of spruce woody biomass. In this work, using diluted sulfuric acid hydrolysis the most efficient species were: Balfourodendron riedelianum $27.03 \%$, Nectandra lanceolata 26.06\% and Myroxylon peruiferum 24.07\% (Figure 4). According to the results, all acids demonstrated to have almost equal efficiency in hydrolysis process carried out in lignocellulosic material used in this work. So the use of other acids for hydrolysis emerges as a value discover for ethanol process improvements.

The most efficient species in obtaining higher diluted phosphoric acid $\left(\mathrm{H}_{3} \mathrm{PO}_{4}\right)$ hydrolysis rates were: Balfourodendron riedelianum 26.79\%, Brosimum 24.89\% and Nectandra lanceolata $24.70 \%$ species as demonstrated in (Figure 5). 
Figure 5: Hydrolysis efficiency by using phosphoric acid $\left(\mathrm{H}_{3} \mathrm{PO}_{4}\right)$

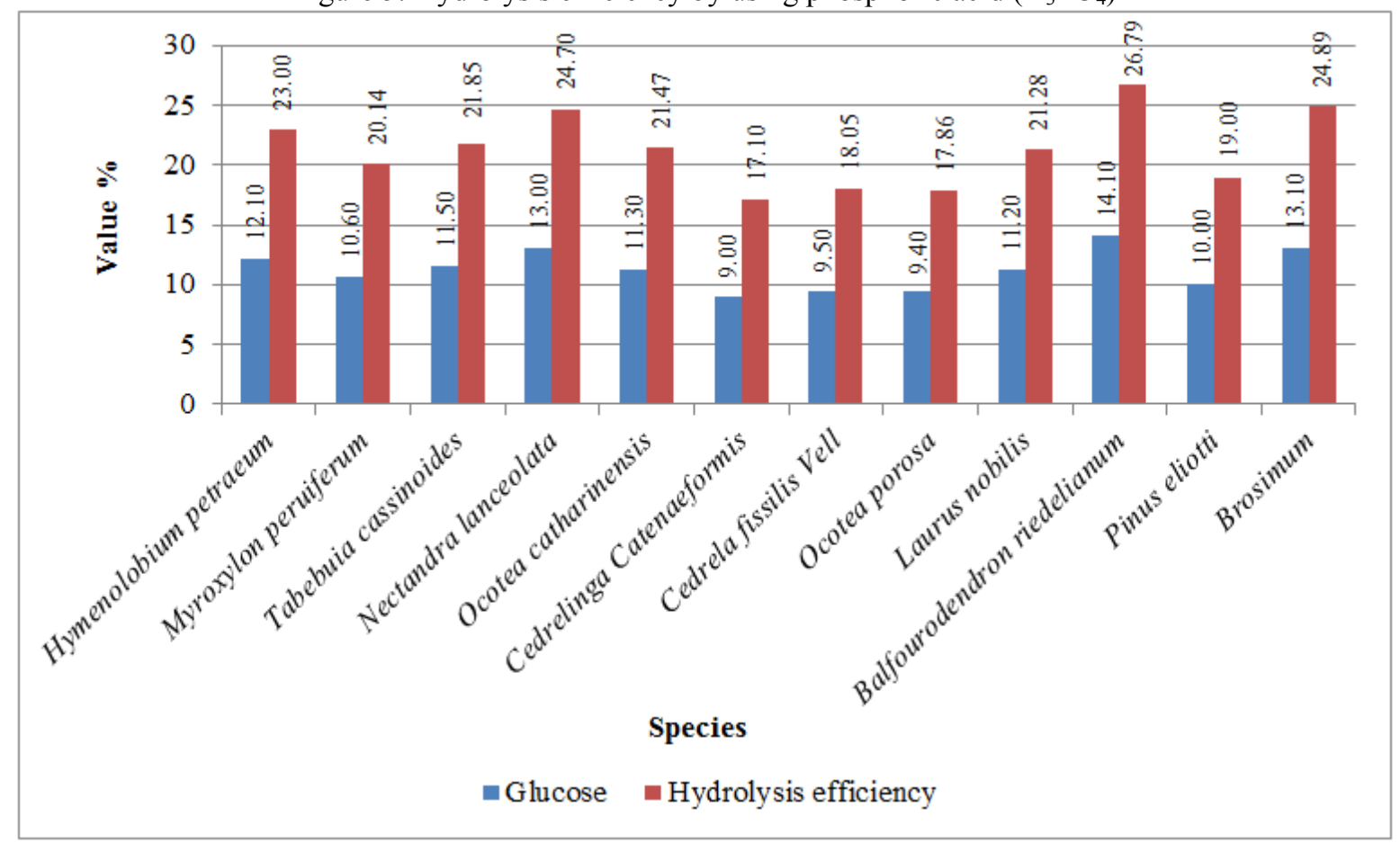

Source: Authors (2011)

From this results it's possible to understand that even with high hydrolysis yields, the glucose recovery becomes difficult, from most acids between 10\% difference between hydrolysis efficiency and glucose recovery. Using phosphoric acid, hydrolyzed cellulose rates stayed between $8.10 \%$ and $12.69 \%$ and glucose recovery rates between $9.0 \%$ and $14.10 \%$ (Figure 5 ).

Starting for the determination of cellulose constitution and glucose recovery levels in hydrolysis per species (Figure 2); (Figure 3); (Figure 4); (Figure 5) according to the results, it's possible now to calculate the estimate capacity of ethanol production per species/100 $\mathrm{kg}$ of utilized biomass by using different acids. In the other hand, the species which demonstrated the largest yields of glucose among all tested acids were: Myroxylon peruiferum, Nectandra lanceolata and Balfourodendron riedelianum.

\subsection{Estimation of ethanol production per acid and per species}

The (Figure 6); (Figure 7); (Figure 8); and (Figure 9); demonstrates the results using estimation for the ethanol production by using acetic, nitric, phosphoric and sulfuric acids. In this work, hydrolysis, fermentation and distillation processes were performed in laboratorial scale resulting in minimum quantities $(1,000 \mathrm{ml}$ per species) So, the using of calculus was necessary for carry out an ethanol production estimative in large scale which is given in liters per $100 \mathrm{~kg}$ of biomass as explained at this work session (2.7). 
Figure 6: Estimation of ethanol capacity of production per species by using acetic acid $\left(\mathrm{CH}_{3} \mathrm{COOH}\right)$

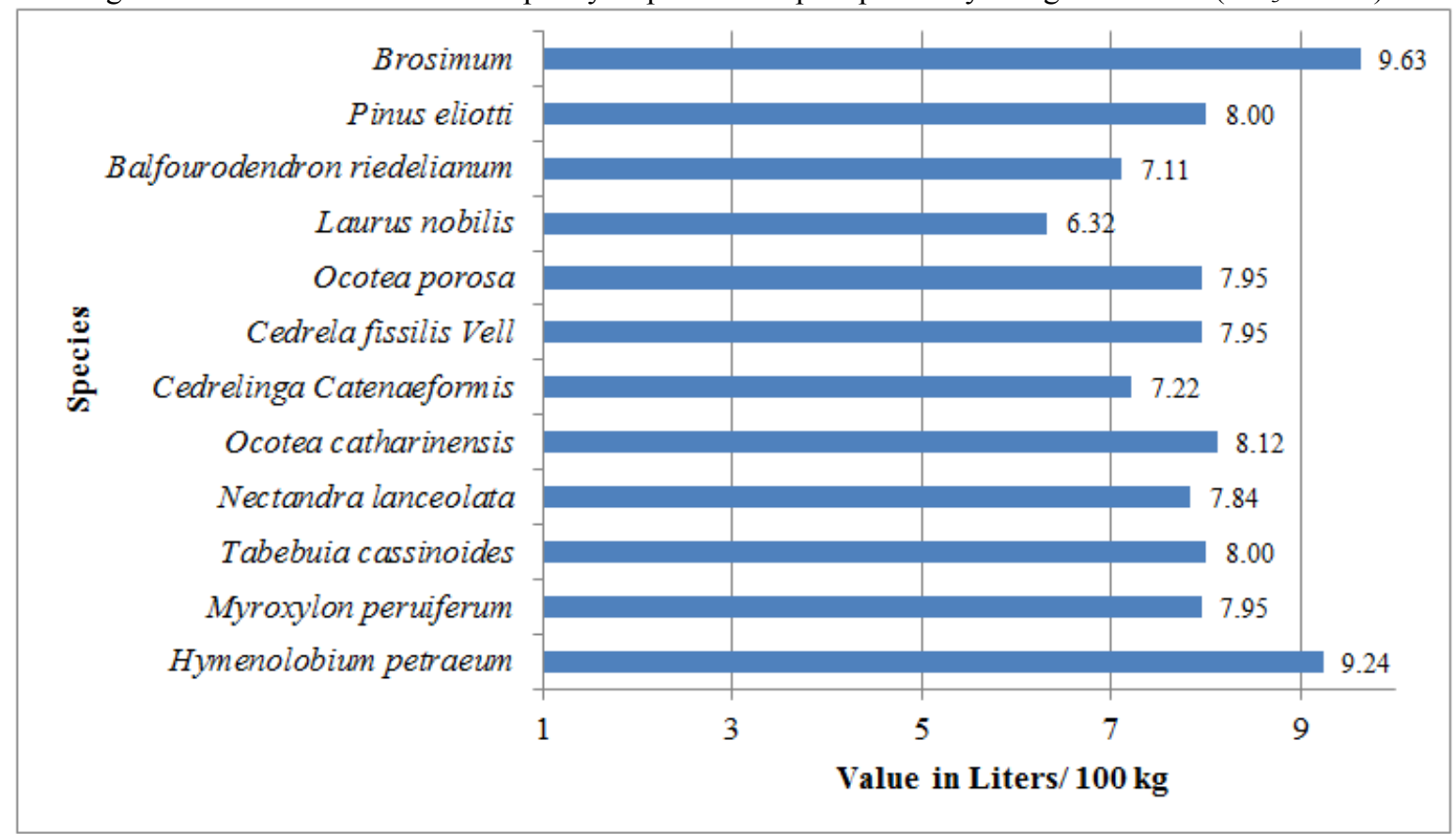

Source: Authors (2011)

According to the results, by using acetic acid hydrolysis performed the estimate ethanol rates per $100 \mathrm{~kg}$ of biomass were inside the range of 9.63 liters $/ 100 \mathrm{~kg}$ using Brosimum, and 6.32 1/100 kg using Laurus nobilis (Figure 6).

Figure 7: Estimation of ethanol capacity of production per species by using nitric acid $\left(\mathrm{HNO}_{3}\right)$

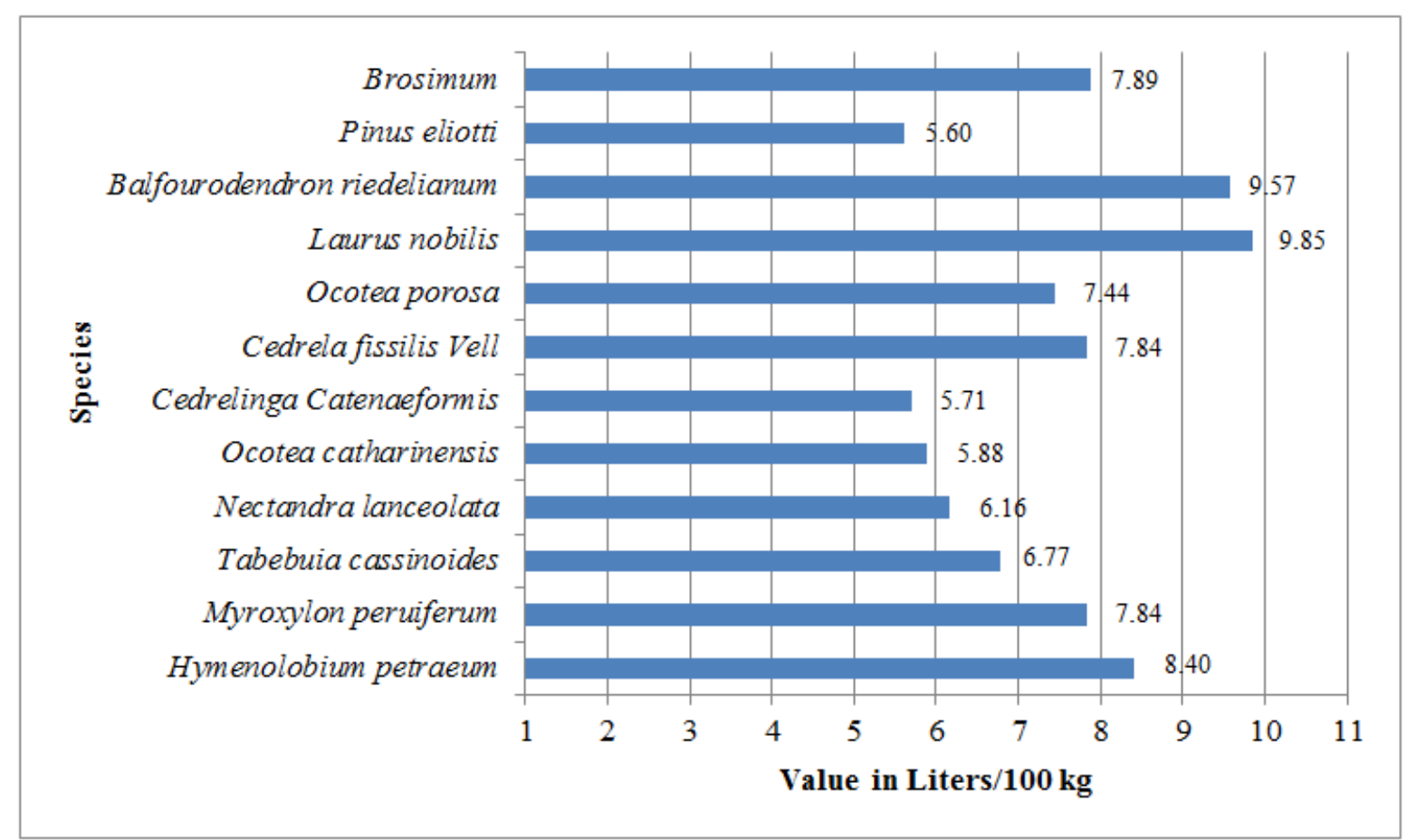

Source: Authors (2011)

Hydrolysis performed using nitric acid, showed good results due to $\left(\mathrm{HNO}_{3}\right)$ affinity reaction to break down cellulose into glucose, and the specimens: Balfourodendron riedelianum Laurus 
nobilis and Hymenolobium petraeum showed hydrolysis yields even better than using sulfuric $\left(\mathrm{H}_{2} \mathrm{SO}_{4}\right)$ and as showed in (Figure 7). The ethanol rates using this acid stayed between 5.60 1/100 kg using Pinus Elliotti and 9.85 1/100 kg using Laurus nobilis using diluted sulfuric treatment.

Figure 8: Estimation of ethanol capacity of production per species by using phosphoric acid $\left(\mathrm{H}_{3} \mathrm{PO}_{4}\right)$

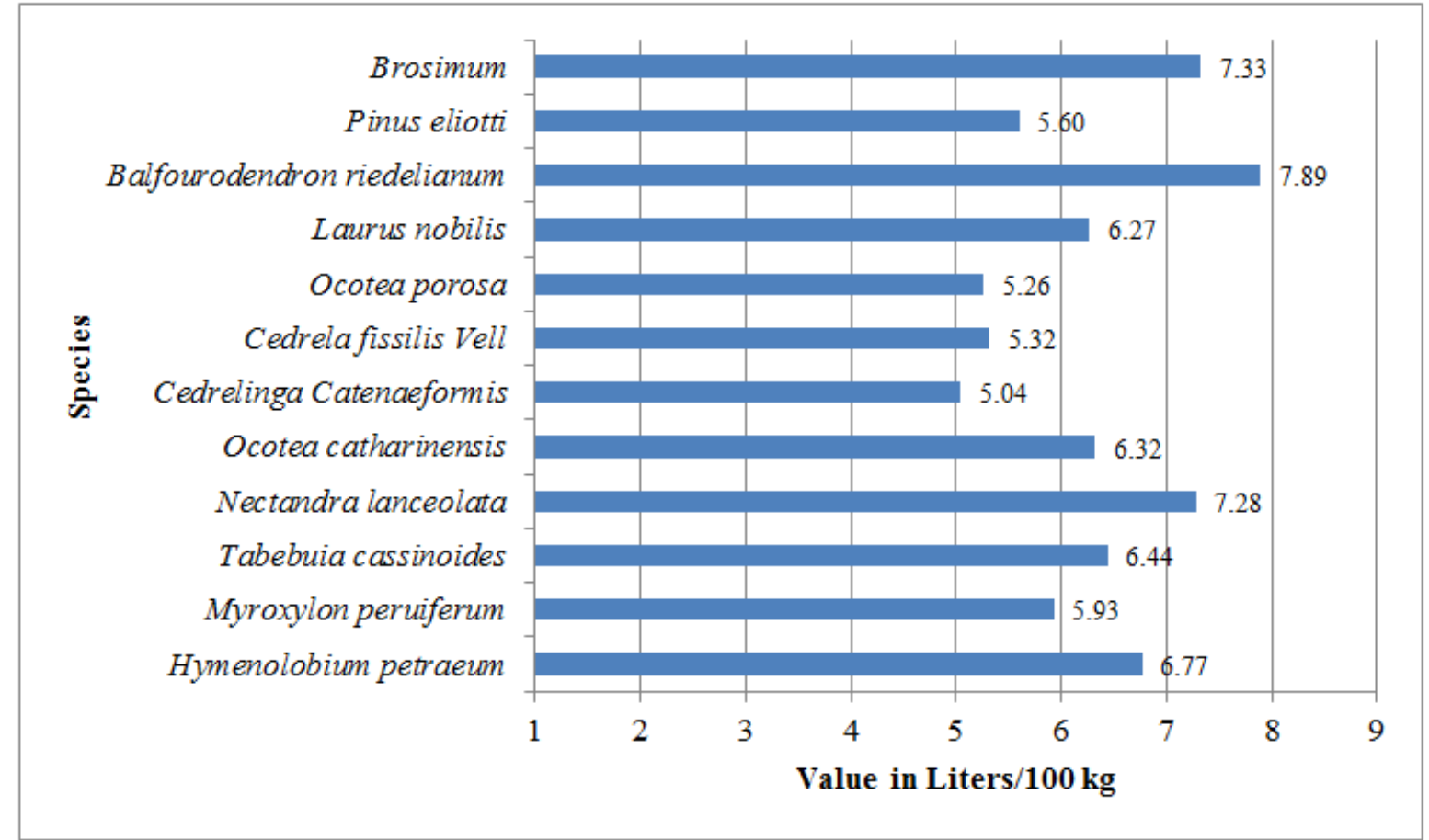

Source: Authors (2011)

Figure 9: Estimation of ethanol capacity of production per species by using sulfuric acid $\left(\mathrm{H}_{2} \mathrm{SO}_{4}\right)$

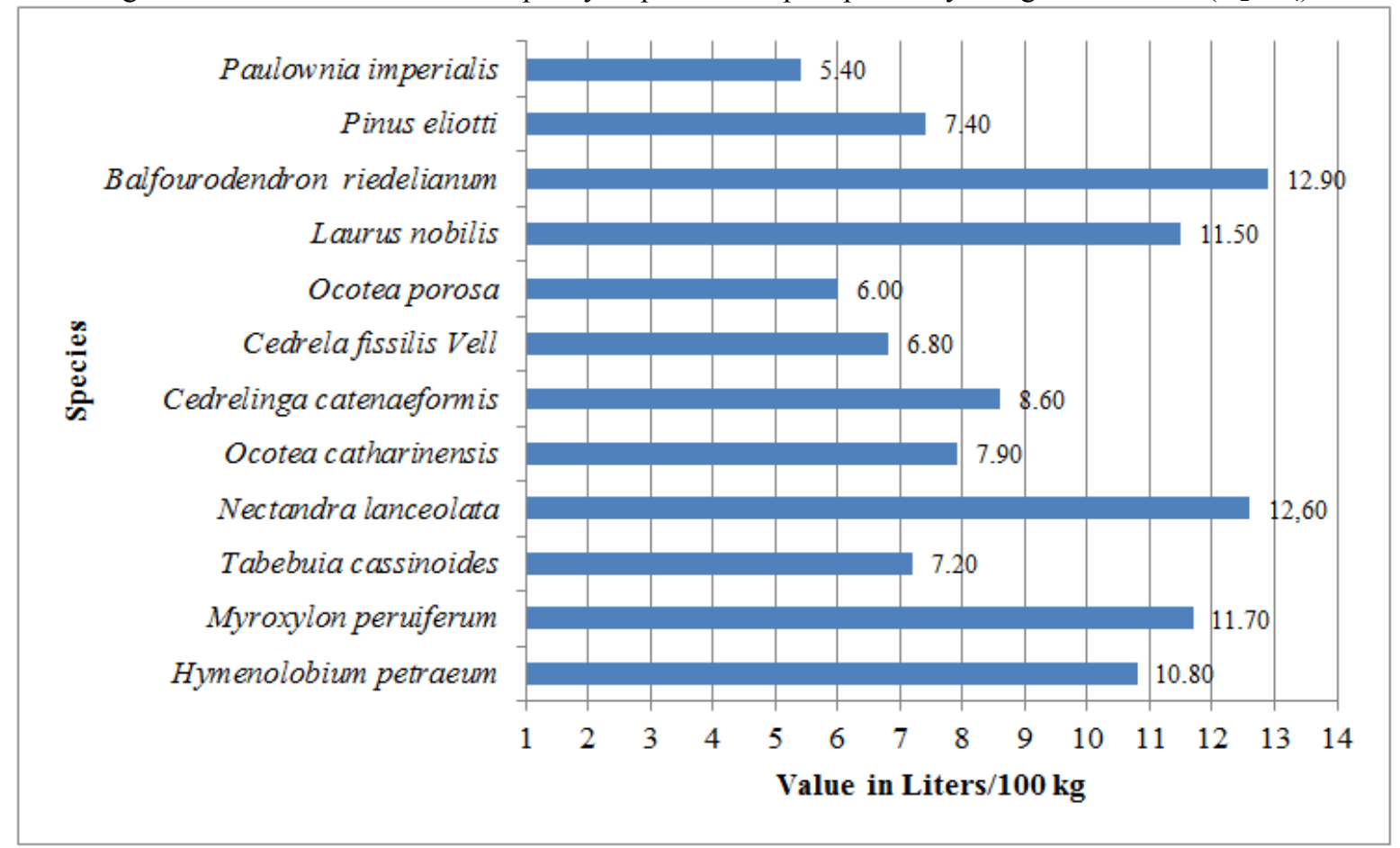

Source: Authors (2011)

The species: Balfourodendron riedelianum, Brosimum and Nectandra lanceolata were the efficient species in estimate capacity of ethanol production using phosphoric acid $\mathrm{H}_{3} \mathrm{PO}_{4}$ (Figure 8). 
The ethanol rates using this acid stayed between 5.04 1/100 kg using Cedrelinga catenaeformis and 7.891 using Balfourodendron riedelianum per $100 \mathrm{~kg}$ of used biomass.

Using sulfuric acid $\mathrm{H}_{2} \mathrm{SO}_{4}$, Balfourodendron riedelianum, Nectandra lanceolata and Myroxylon peruiferum demonstrated to be the most efficient producers of ethanol (Figure 9). The ethanol rates using this acid stayed between 5.40 1/100 kg using Pinus Elliotti and 12.90 1/100 kg using Balfourodendron riedelianum. According to the results, (Figure 10) it's possible to visualize a comparative between acid and alkaline pretreatment for delignification's and fibers production efficiencies respectively.

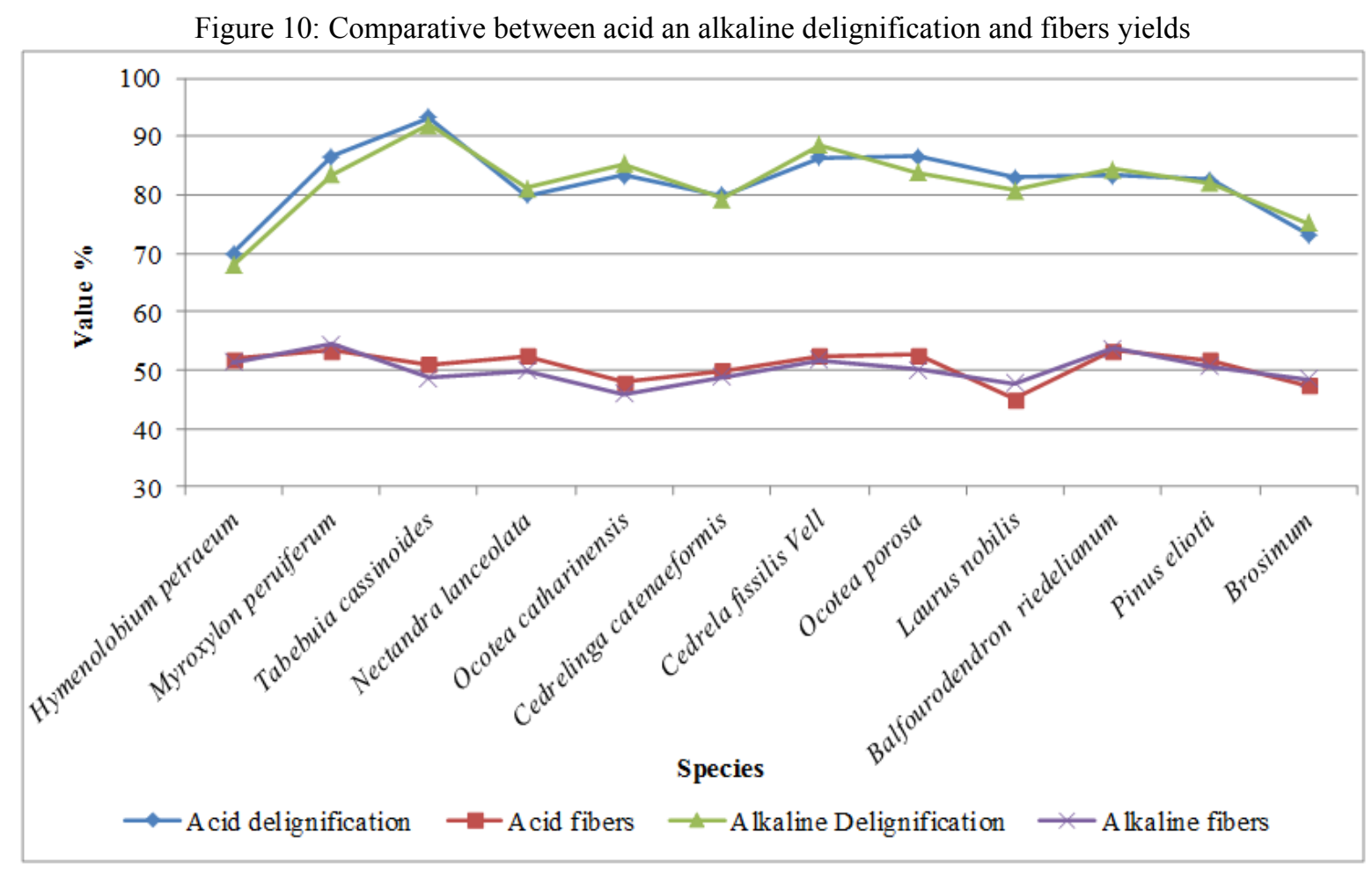

Source: Authors (2011)

Acid and alkaline delignification's demonstrated to be similar in efficiency, and the results depends much of the chemical constitution from species to species. Also depends, the separation of lignin from fibers by using acid and alkaline treatments as can be observed (Figure 10). In (Figure 11) it's possible to visualize a comparative between the hydrolysis efficiency by using the different acids. A comparative between the glucose recoveries per acids is demonstrated in (Figure 12). And finally, a comparative between ethanol capacities of production using different acids is demonstrated in (Figure 13). There's differences between the hydrolysis yields by using the different acids: Nitric acid, phosphoric and acetic mainly. This indicates that these acids are feasible substitutes for diluted sulfuric acid. Also here, the hydrolysis efficiency appears to be related with the chemical constitution of analyzed species. 
Figure 11: Comparative between acid hydrolysis yields

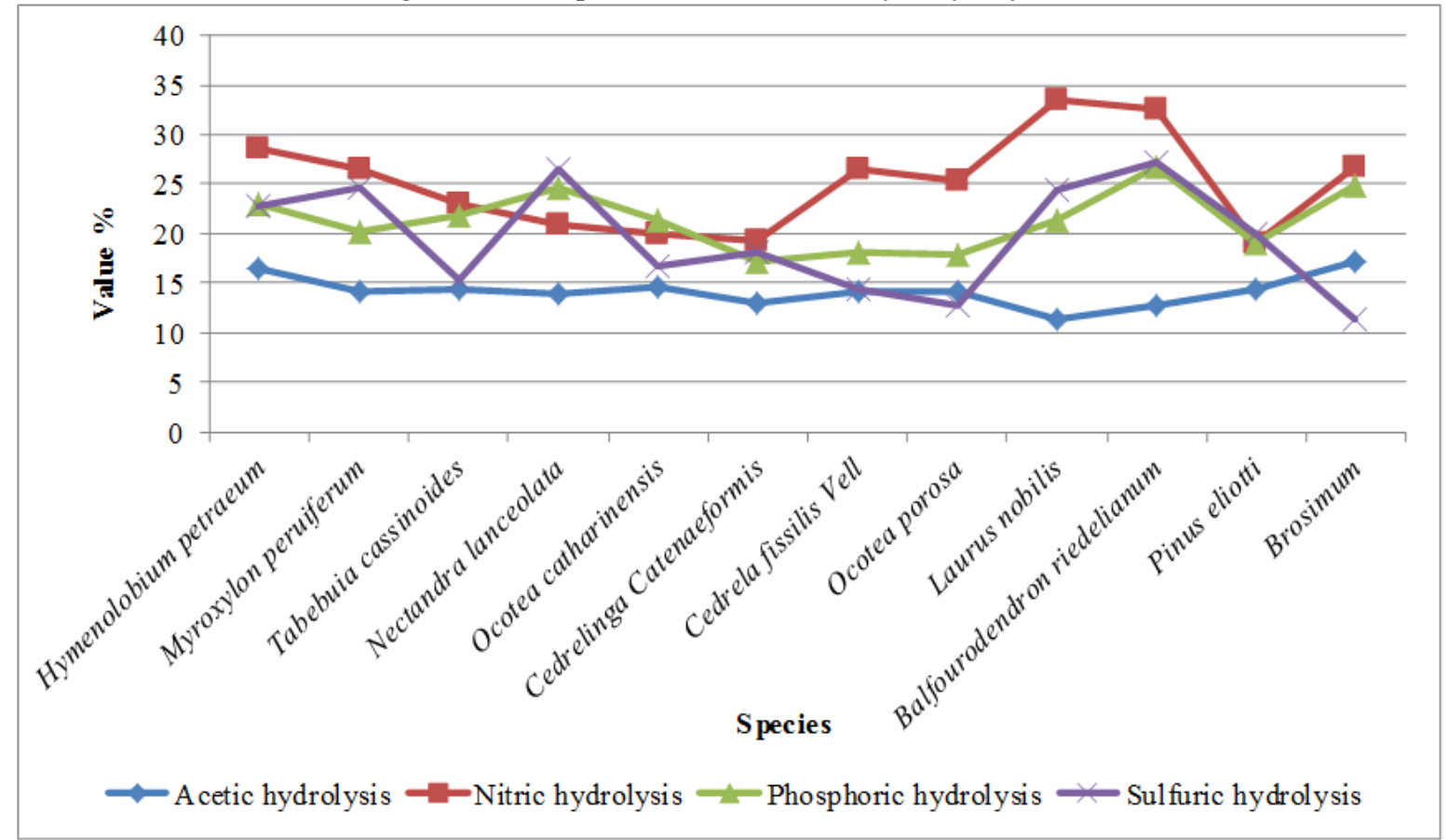

Source: Authors (2011)

The most efficient acid in cellulose hydrolysis was nitric acid, followed by sulfuric, phosphoric and acetic. But it depends from species to species. Variations between hydrolysis yields demonstrated to be within the range of $10 \%$ and $35 \%$.

Figure 12: Comparative between glucose yields

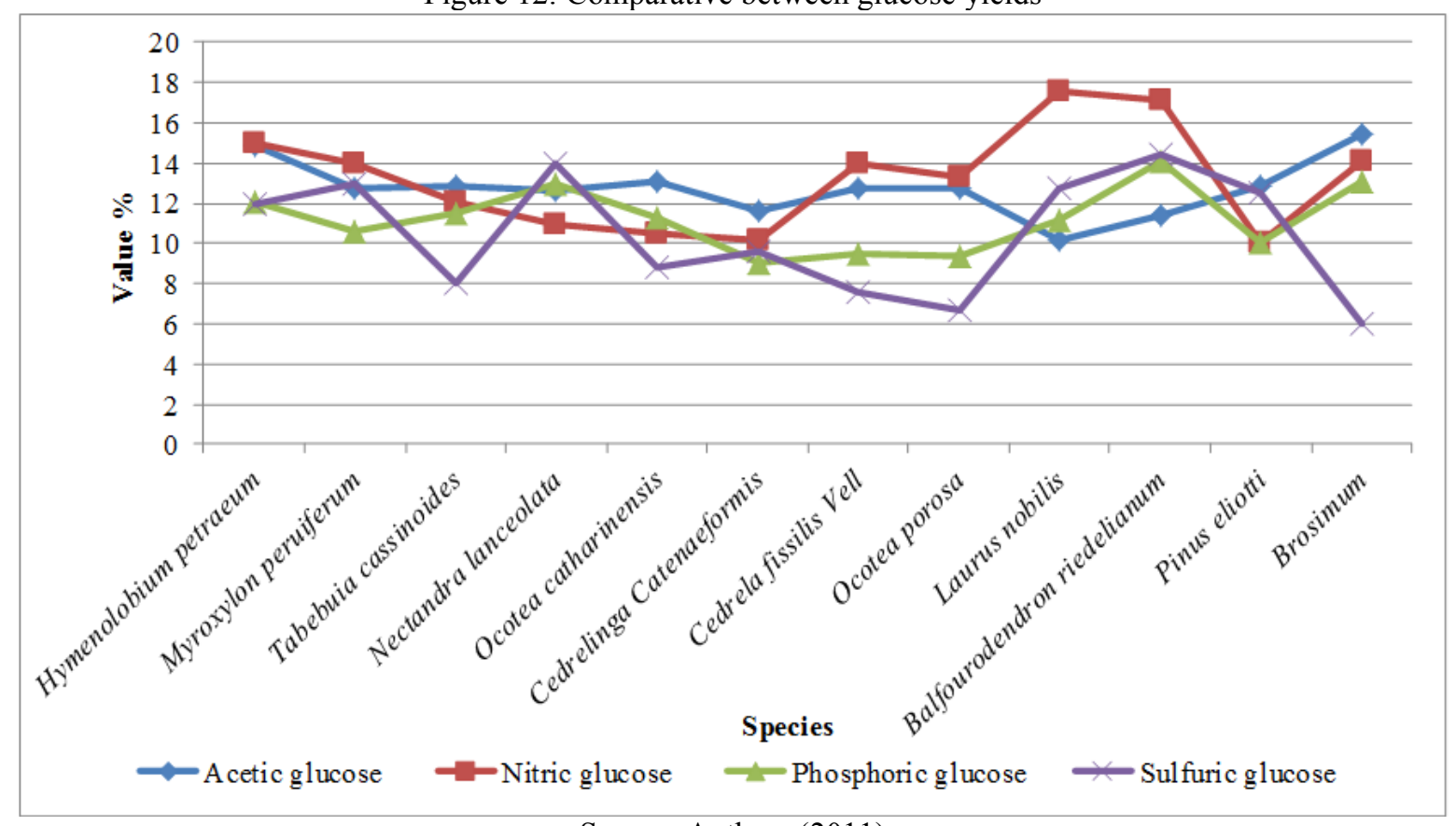

Source: Authors (2011)

As possible to see in (Figure 12), a glucose recovery 6\% and $18 \%$ depending of the specie performed. This indicates that these rates of glucose can be directly fermented by the yeast and the fibers can keep maintained (Figure 10). 
Figure 13: Comparative between ethanol yields

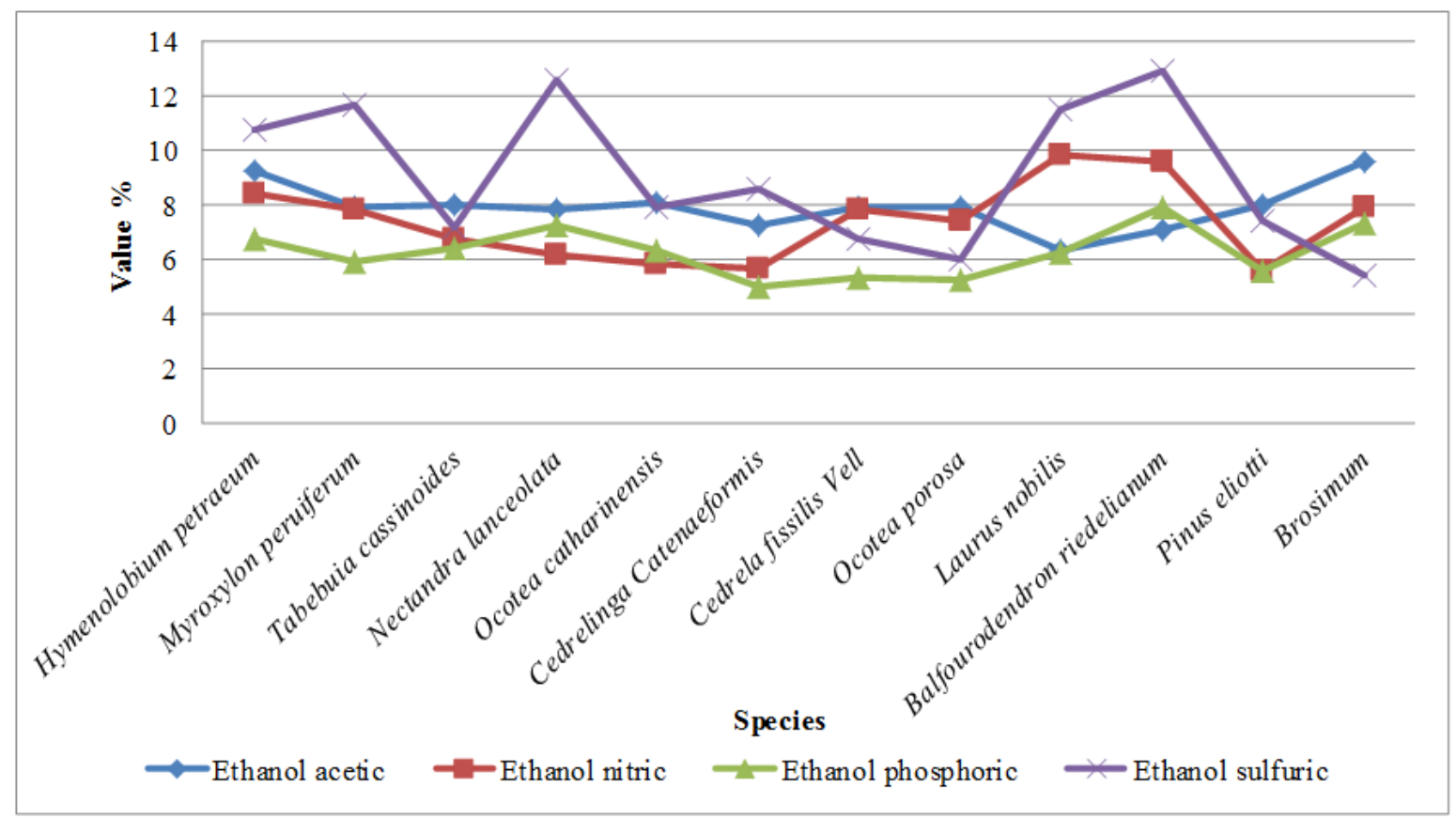

Source: Authors (2011)

A production of ethanol using sulfuric acid demonstrated to produce more ethanol per 100 $\mathrm{kg}$ of biomass followed by nitric, acetic and phosphoric acids, respectively (Figure 13). The ethanol yields demonstrated to be inside the range of $4 \%$ and $14.0 \%$ efficiency.

\section{Conclusion}

In this study the use of nitric, sulfuric, phosphoric and acetic diluted acid hydrolysis represents an interesting alternative for bioethanol production and its also possible to simultaneosly produce fibers from Brazilian wood wastes. Savage line of Saccharomyces cerevisiae demonstrated to be very efficient in ethanol production, with an estimate production inside the range of 12.90 liters per $100 \mathrm{~kg}$ of biomass using Balfourodendron riedelianum specimen and $\left(\mathrm{H}_{2} \mathrm{SO}_{4}\right)$ and 5.04 using Cedrelinga catenaeformis and $\left(\mathrm{H}_{3} \mathrm{PO}_{4}\right)$ diluted acid hydrolysis. Generally, all acids demonstrated great and similar efficiency. The distillatory process occurred in laboratorial scale and due to the minimum quantities of ethanol produced it was necessary to use calculus in the estimation of ethanol production for large scale. The delignification levels by using acid and alkaline treatments demonstrated to be feasible for lignin separation and yielded good fibers content, which both could be used industrially as byproducts. Also, all acids and samples demonstrated potential for use in fibers and bioethanol production, and seemed to be influenced mainly by the chemical constitution of species.

\section{Resumo}

O objetivo deste trabalho foi determinar a eficiência de hidrólise utilizando quatro diferentes tratamentos ácidos 
diluídos: ácido sulfúrico $\left(\mathrm{H}_{2} \mathrm{SO}_{4}\right)$, nitrico $\left(\mathrm{HNO}_{3}\right)$, fosfórico $\left(\mathrm{H}_{3} \mathrm{PO}_{4}\right)$ e acético $\left(\mathrm{CH}_{3} \mathrm{COOH}\right)$, na tentativa de melhorar e os níveis de produção de fibras e de bioetanol. Neste estudo doze madeiras brasileiras foram investigadas, incluindo espécies nativas e exóticas, madeiras duras e macias. Foram utilizados processos para a recuperação de resíduos de madeira para produzir fibras celulósicas e etanol simultaneamente. Para os ensaios de fermentação, uma linha selvagem da levedura Saccharomyces cerevisiae foi investigada. Os rendimentos relacionados com a eficiência de hidrólise eficiência das frações fibrosas, glicose além dos níveis de deslignificação utilizando tratamento ácido e alcalino foram testados. A partir dos resultados é possível produzir fibras celulósicas e etanol simultaneamente utilizando cavacos de madeira, e devido à complexidade do material analisado ainda é possível isolar derivados os quais podem ser utilizados como biprodutos. A levedura mostrou-se eficiente, com uma estimativa de produção máxima de 12,94 litros por cada $100 \mathrm{~kg}$ de biomassa por meiode amostra Balfourodendron riedelianum e hidrólise com ácido sulfúrico. Todos os ácidos demonstraram semelhantes e elevadas eficiências e quanto à hidrólise, indicando que esses ácidos são viáveis para o uso de processos de hidrólise.

Palavras-chave: hidrólise; ácidos diluídos; resíduos de madeira; fibras celulósicas; bioetanol.

\section{References}

CARDONA, C. A.; QUINTERO, J. A.; PAZ, I. C. Production of bioethanol from sugar cane bagasse: status and perspectives. Bioresource Technology. v. 101, n.13, p. 4754-4766, 2010.

\section{cross ${ }^{\text {ref }}$}

COPPOLA, F.; BASTIANONI, S.; OSTERGARD, H. Sustainability of bioethanol production from wheat with recycled residues as evaluated by energy assessment. Biomass \& Bioenergy. v. 33, p. 1626, 2009.

cross ${ }^{\text {ref }}$

CHUM, H. L.; JOHNSON, D. K.; BLACK, S. K.; OVEREND, R. P. Pretreatment catalyst effects and the combined severity parameter. Applied Biochemistry and Biotechnology. v. 24-25, p 1-14, 1990.

cross ${ }^{\text {ref }}$

FENGEL, D.; WEGENER, G. Wood. Chemistry. Ultrastructure. Reactions. Walter de Gruyter. Berlin, 1989.

IRANMAHBOOB, J.; NADIM, F.; and MONEMI S. Optimizing acid-hydrolysis: a critical step for production of ethanol from mixed wood chips. Biomass \& Bioenergy, v. 22, p. 401-404, 2002.

cross ${ }^{\text {ref }}$

KAKANSON, H.; HLGREN, P. Acid hydrolysis of some industrial pulps: effect of hydrolysis conditions and raw material. Cellulose. v. 12, p. 177-183, 2005.

cross'ref

KRISHNA, S. H.; REDDY, T. J.; CHOWDARY G. V. Simultaneous saccharification and fermentation of lignocellulosic wastes to ethanol using a thermotolerant yeast. Bioresource Technology. v. 77, p193-196, 2001

cross ${ }^{\text {ref }}$

LEWIN, M.; OLDSTEIN, I. Wood Structure and Composition, International Fiber. M. Dekker, New York. 1991.

LIU, S. A kinetic model on autocatalytic reactions in woody biomass hydrolysis. J. Biobased Mater. Bioenergy. v. 2 , p. $135-147,2008 \mathrm{a}$.

\section{crossef}

LIU, S.; et al. Wood Membrane filtration: concentration and purification of hydrolyzates from biomass. J. Biobased Mater. Bioenergy. v. 2, p. 121-134, 2008b.

cross ref

MARTÍN, C.; ÖNSSON. L. J. Comparison of the resistance of industrial and laboratory strains of Saccharomyces cerevisiae and Zygosaccharomyces to lignocellulose-derived fermentation inhibitors. Enzyme Microb. Technol, v. 32 , p. $386-395,2003$.

cross ${ }^{\text {ref }}$

MCMILlAN, J. D. Conversion of hemicellulose hydrolysates to ethanol, In: HIMMEL et al., (eds) Enzymatic conversion of biomass for fuel production. Washington D.C., ACS Symposium Series. v. 566, p. 411, 1994. 
OLIET, M. et al. The effect of autocatalized etanol pulping on lignina characteristics. J. of Wood Chem. Technol. v. 21, p. 82-95, 2001.

cross ref

PAN, X. J.; SANO, Y. Comparison of acid lignin with milled wood and alkaline lignins from wheat straw. Holzforschung. v. 54, p. 61-65, 2000.

cross ref

SASAKI, M. et al. Cellulose hydrolysis in subcritical and supercritical water. J. Supercrit. Fluids. v. 13, p. 261-268, 1998.

cross ref

SUN, Y.; HENG, J. Hydrolysis of lignocellulosic materials for ethanol production: a review. Bioresource Technology. v. 83, p. $1-11,2002$.

cross'

SUN, X. F. et al. Characteristics of degraded lignin obtained from steam exploded wheat straw. Polymer degradation and Stability. v. 86, p. 245-256, 2004.

cross ${ }^{\text {ref }}$

TAHERZADEH, M. J.; MILlATI, R.; NIKLASSON, C. Continuous cultivation of dilute-acid hydrolysates to ethanol by immobilized Saccharomyces cerevisiae. Appl. Biochem. Biotechnol. v. 95, p. 45-50, 2001.

cross ref

URAKI, Y. et al. Activated carbon from acetic lignin. Holzforschung. v. 51, p. 188-192, 1997.

crossef

VILA, C.; SANTOS, V.; PARAJO, J. C. Recovery of lignin and furfural from acetic acid-water-HCl pulping liquors, Bioresource Technol. v. 90, p. 339-344, 2003.

cross ${ }^{\text {ref }}$

WOICIECHOWSKI, A. L. et al. Acid and enzymatic kydrolysis to recover reducing sugars from cassava bagasse: an economic study. Brazilian Archives of Biology and Technology. Curitiba, v. 45 n. 3, p.400, 2002.

\section{cross ${ }^{\text {ref }}$}

XAVIER, A. M. R. B. et al. Second generation bioethanol from eucalyptus sulphite spent liquor. Bioresource Technology. v. 101 n. 8, p. 2755-2762, 2010.

cross $^{\text {ref }}$

XU, F. et al. Comparative study of organosolv lignins from wheat straw. Ind. Crops and Prod. v. 23, p. 180-193, 2006. cross ${ }^{\text {ref }}$

YANG, B.; WYMAN, C. E. BSA treatment to enhance enzymatic hydrolysis of cellulose in lignin containing substrates. Biotechnol Bioeng. v. 94, p. 611, 2006.

cross ${ }^{\text {ref }}$

ZHU, J. Y.; PAN, X. J. Woody biomass pretreatment for cellulosic ethanol production: technology and energy consumption evaluation. Bioresource Technology. v. 101, p. 4992-5002, 2010a.

cross ${ }^{\text {ref }}$

ZHU, R. et al. Dilute sulfuric acid hydrolysis of sugar maple wood extract at atmospheric pressure. Bioresource Technology. v. 101 n. 10, p. 3586-3594, 2010 b.

cross ${ }^{\text {ref }}$

ZHANG J. et al. Isolation and characterization of wheat straw lignin with a formic acid process. Bioresource Technology. v. 101, n. 7, p. 2311-2316, 2010.

cross ref

\section{Dados dos autores}


Nome completo: Diogo José Horst

Filiação institucional: Universidade Tecnológica Federal do Paraná - UTFPR, Campus Ponta Grossa.

Departamento: Pós-Graduação em Engenharia de Produção

Função ou cargo ocupado: Mestrando em Engenharia de Produção / Bolsista Demanda Social CAPES

Endereço completo para correspondência (bairro, cidade, estado, país e CEP): Avenida Monteiro Lobato, Km 4, Pitangui. Ponta Grossa - Paraná - Brasil. CEP: 84016-210.

Telefones para contato: (47) 8449-2623

e-mail:diogohorst@yahoo.com.br

Nome completo: Rodolfo Reinaldo Petter

Filiação institucional: Universidade Tecnológica Federal do Paraná - UTFPR, Campus Ponta Grossa.

Departamento: Pós-Graduação em Engenharia de Produção

Função ou cargo ocupado: Mestrando em Engenharia de Produção / Bolsista Pró-Engenharias UFPE/UTFPR - CAPES

Endereço completo para correspondência (bairro, cidade, estado, país e CEP): Avenida Monteiro

Lobato, Km 4, Pitangui. Ponta Grossa - Paraná - Brasil. CEP: 84016-210.

Telefones para contato: (49) 9971-5494

e-mail:rodolfo@jjcmoveis.com.br

Nome completo: Jhon Jairo Ramirez Behainne

Filiação institucional: Universidade Tecnológica Federal do Paraná - UTFPR, Campus Ponta Grossa.

Departamento: Pós-Graduação em Engenharia de Produção

Função ou cargo ocupado: Professor titular do Programa de Pós-Graduação em Engenharia de Produção.

Endereço completo para correspondência (bairro, cidade, estado, país e CEP): Avenida Monteiro Lobato, Km 4, Pitangui. Ponta Grossa - Paraná - Brasil. CEP: 84016-210.

Telefones para contato: (42) 3220-4876

e-mail:jhon@utfpr.edu.br

Enviado em: 07/02/2011

Aprovado em: 28/06/2011 